\title{
15 Marketing Anglophone World Literatures
}

\begin{abstract}
From the nineteenth century onwards, world literature has been closely connected to socio-economic reasoning, which has shaped (and continues to shape) how it is disseminated, received, and produced. Based on first marketing considerations by writers in the nineteenth century, this chapter outlines the importance of 'glocal' Anglophone literary markets and explores key developments and challenges in marketing Anglophone world literatures. In addition to investigating the seminal roles played by publishers, literary agents, and retailers, it discusses the impact of literary prizes, such as the Booker Prize, in the attention economy as well as growing trends of self-marketing, self-publishing, and the role of small online platforms in promoting national literatures and disseminating the works of both established and upcoming writers.
\end{abstract}

Key Terms: Marketing, publication industry, Booker Prize, self-publishing, glocality

\section{A Tale of Two Markets: The Glocality of World Literatures}

Samuel Langhorne Clemens knew the tricks to marketing world literature perfectly well. At least that is what the preface to The Gilded Age: A Tale of Today (1873), co-written by Clemens, alias Mark Twain, and Charles Dudley Warner, seems to suggest. Attuning their readers to a novel which is set during an age of unprecedented industrial and technological growth, which marked the beginning of "the consumer revolution" (Applbaum 2004, 173), they disclose the rationale behind the design of the narrative:

Our quotations are set in a vast number of tongues; this is done for the reason that very few foreign nations among whom the book will circulate can read in any language but their own; whereas we do not write for a particular class or sect or nation, but to take in the whole world. [...] One word more. This is - what it pretends to be a joint production, in the conception of the story, the exposition of the characters, and in its literal composition. There is scarcely a chapter that does not bear the marks of the two writers of the book.

(Twain 1996 [1873], v)

The pronounced self-fashioning of the work as a multinational, polyvocal, and universal novel, which meets the requirements of the global literary market, however, turns out to be mere pretence (cf. Morris 2011). Though the epigraphs are multilingual, the novel was clearly written for an English-speaking readership, more precisely - considering its critique of fictitious capital circulated by Wall Street investors - for the 
American market. And yet, the preface points to the effects of global trade structures on individual writers and national book industries, while ironically acknowledging the need for self-marketing as well as the dominance of the English language in this endeavour - aspects that point to key concerns regarding the marketing of Anglophone world literatures, i.e. literatures that emerge from Anglophone centres of publishing, while marketed as 'world literatures'.

Due to the lack of international copyright (which was not introduced until 1891), the nineteenth-century American book market was dominated by pirated or cheaply obtained European works and imported Canadian imprints, which were promoted at the expense of American writers who feared a decline in national literature. The tension between the local, the national, and the global points to a dilemma that is also ingrained in the notion of 'Anglophone world literatures'.

As indicated by Twain's and Warner's preface, the market for world literatures, though geared towards transnationalism, is ultimately either rooted in the negotiation between the local and the global, or doomed to commercial failure. This is also suggested in J.M. Coetzee's Elizabeth Costello (2003), a novel that could be classified as 'Anglophone world literature', which also reflects upon the marketing of world literatures. As the protagonist remarks, besides “[t]he English Novel”, which "is written in the first place by English people for English people” (Coetzee 2003, 51), Anglophone literatures are tailored to an international market. Consequently, writers are cut off from their roots and their national heritage, as in the case of the African novel:

[T]he African novel is not written by Africans for Africans. African novelists may write about Africa, about African experiences, but they seem to me to be glancing over their shoulder all the time they write, at the foreigners who will read them. Whether they like it or not, they have accepted the role of interpreter, interpreting Africa to their readers.

(Coetzee 2003, 51)

According to Elizabeth Costello, the increasing demand for global literatures jeopardizes authenticity in favour of marketing considerations for it forces novelists to anticipate and satisfy the needs and desires of a specific (Western) readership. The African writer Emmanuel Egudu, however, is encouraged to revise this strategy and follow the model of Australian literature, proposed by Costello:

[W]e in Australia have been through similar trials and have come out at the other end. We finally got out of the habit of writing for strangers when a proper Australian readership grew to maturity, something that happened in the 1960s. A readership, not a writership - that already existed. We got out of the habit of writing for strangers when our market, our Australian market, decided that it could afford to support a home-grown literature. This is the lesson we can offer. This is what Africa could learn from us.

(Coetzee 2003, 51-52)

This rise of local publishing Costello refers to was supported by increased government funding for the arts, which enabled a period of independence from "the longstanding dominance of British publishers in the Australian book market” (Bode 2012, 58). Even though government funding receded in the 1990s and the pressures of the global 
economy opened up the market again to multinational publishers, Australian literatures continue to thrive (cf. Bode 2012, 58-60).

Reminding readers of the advantages of fostering a distinctly Australian market, based on national sentiments which enabled Australian literature to flourish, Coetzee underscores what the marketing of Anglophone literatures should refrain from, i.e. promoting literatures that are deliberately composed for an international market and occupied with "strategic Occidentalism" (Prado 2018). Instead, it should embrace plurality by fostering national literatures and - not driving but following - literary production. In this respect, Anglophone world literature markets should strive to be 'glocal', insofar as they are essentially "home-grown" (Coetzee 2003, 52), to recognize the global and the local as interdependent, and to acknowledge the impact of the local on global politics and processes (cf. Neumann 2020).

As a consequence, the marketing of world literatures should concentrate on globally distributing literatures produced in local contexts (cf. Steiner 2012, 323) while responding to local demands and preserving "something untranslatable", which could foster "mondialisation” (Nancy 2004, 28; see Neumann/Rippl 2017). Above all, world literature is a collaborative endeavour ( $\nearrow 1$ The Beginnings of the Concept and $\nearrow 2$ Re-Reading Classical Approaches), driven first and foremost by marketing considerations. 'World literature' was born both as "an aspiration and a market-based reality" (Puchner 2017, n.pag.), promoted by "a human network of sorts that spans across the globe and is possible only through literature, which is in turn facilitated by trade and commerce” (Xavier 2016, 26).

\section{The Publication Industry and Self-Marketing}

"There is no denying that world literature is a market, one in which local and national literatures can meet and transform each other. World literature depends, above all, on circulation" (Puchner 2017, n.pag.). And yet, as Ann Steiner has indicated, "there is no such thing as a truly international book trade" (2012, 317). Instead, the global book market is governed by (Western) metropoles, which hold "[t]he huge power of being able to say what is literary and what is not” (Casanova 2004, 21-23) and which shape literary markets by determining the 'value' of a specific work and its tradability. These trading processes are guided by "rivalry, struggle, and inequality” $(2004,4)$ tensions that need to be negotiated on the national and global level, between small and big publishers, local and international readerships, but which are often 'solved' by globally recognized, large publishing corporations, including Penguin Random House and the Hachette Group (cf. Arts Council 2017, 21).

During the past 15 years, the book-marketing industry has changed from a product-oriented to a market-oriented approach. While before, the search for markets happened after the product was created, the publishing industry today identifies 
market segments to tailor (and alter) their products to meet specific customers' demands: "Marketing is about offering: the right people; the right product, the right price; the right promotional approach; the right way; at the right time; in the right place" (Baverstock 2015, 9).

Which is 'the right product', 'the right price', and the 'right time' and 'place' is predominantly decided by publishers, who are the unrecognized legislators of the literary market. They accept or reject manuscripts, assess the marketability of a work, and determine which books will be produced and which will be translated, thereby creating "hegemonic force fields" (Pizer 2012, 9), which set language trends and thus support the proliferation of 'Anglophone world literatures'. Furthermore, publishing companies increasingly invest in marketing activities: “Thirty years ago some firms had only Publishing Departments - and no formal marketing responsibilities [...]. [T] oday they are largely run by marketers” (Baverstock 2015, 6).

As indicated in the opening of this chapter not only publishing houses, but also authors have long recognized the growing need for (self-)marketing. Today, writers increasingly (have to) engage literary agents to gain and maintain access to the literary market. These agents assess the potential 'value' of specific works, based on criteria such as "authenticity", "uniqueness of voice", and "intricacy of plot" ("The Agent: How to Pitch Your Book” n.d., n.pag.), and negotiate and sell publishing rights to individual companies. It is the agents, therefore, that ultimately enable the travelling of literatures and shape the literary market. Their rising number points to the increasingly competitive and rapidly “developing culture of marketing” (Squires 2007, 25) in fiction publication.

Therefore, the pressure, especially on new authors, to become engaged in (self-) marketing activities has increased dramatically. As a consequence, writers' handbooks on how to get published and how to hook an agent, such as the Writers' and Artists' Yearbook, are thriving. Once a work has been accepted by an agent and eventually also found a publisher, marketing activities will be coordinated by professional marketers. Further down the trade chain, bibliomigrancy, i.e. "the physical or virtual movement of books" (Mani 2017, 38), is enabled by retailers and large bookshops, which are responsible for promoting specific works by putting them on display, organizing public readings, or creating bestseller lists, based on their sales numbers.

With the digital turn, however, the marketing pace for literary works has changed. Reviews published in newspapers and magazines are rivalled by criticism on Twitter, Facebook, or digital review platforms, such as GoodReads, which enable immediate responses and reactions. As a result, "[s]ales and marketing have been in the vanguard, maximizing the use of streaming services, hybrids directed straight at customers, social media, YouTube, and a wide range of websites" (Steiner 2018, 120-121). Writers, therefore, often turn to social media and private websites to promote their work.

The effects of the flourishing digital marketplace on world literatures continue to be profound. Grown into a key agent in 'worlding' literature, the internet has further facilitated the 'travelling' of books. As suggested by Venkat Mani, world literature in 
the digital age has become both "cosmochronic and cosmotopic" (2012, 293), which adds a new level to bibliomigrancy. Today, an estimated $75 \%$ of all adult books, both fiction and non-fiction, and around 50\% of all children's books are sold online (cf. Writers' and Artists' Yearbook 2019, n.pag.). Heavyweights, such as Amazon, but also smaller online retailers, have entered the book market with a vengeance. While the former work with algorithms and meticulously devised AI-marketing strategies, designed to respond to individual customers' demands, and are almost unrivalled in catapulting titles from no-names to must-reads, smaller retailers become increasingly important for disseminating Anglophone world literatures, especially as many of them support glocal markets. One example is the African Books Collective (ABC), which emerged from a self-help initiative promoting African literatures overseas. The collective, which was founded jointly by 19 African publishers and includes 154 independent African publishers in 24 countries to date, is a non-profit organisation, supported by fundraising activities. With a small office in Oxford and an online retail service, it serves as a "worldwide marketing and distribution outlet for books from Africa” (African Books Collective n.d., n.pag.). Its aim is threefold: (1) "to provide the most comprehensive selection of relevant material to customers worldwide in the form they require", both in print or print-on-demand and as ebooks; (2) "to achieve ABC's cultural aims whilst operating in a wholly commercial space"; and (3) "to grow the market for African books worldwide" (African Books Collective n.d., n.pag.). In addition to propelling African literatures abroad, ABC strives to increase book sales across the African continent and support indigenous publishers, which are often overshadowed by misguided aid or corruption (cf. Alfredsson 2017).

The digital market not only offers new opportunities for publishers, but also aids authors in countering established "hegemonic force fields" (Pizer 2012, 9) in the Anglophone world. As publishers invest more money in marketing activities, they tend to spend less on remunerating writers and thus drive wages down. Since 2013, the median income of writers in the UK has plummeted by a third, amounting to around 3.000 GBP per year, while UK publishers' profits continue to rise (cf. Kean 2018, n.pag.). As best-selling authors, such as Philip Pullman, Antony Beevor, and Sally Gardner, have pointed out, this exploitation has led to a decline in professional writers, "threatening the diversity and quality of literary culture” (Kean 2018, n.pag.), which not only affects the British literary market, but also the market of Anglophone world literatures, which is largely governed by Western marketing machines.

One way to bypass the traditional publishing industry, enter into the Anglophone market directly, and receive a fair share of the profit gained by one's work, is selfpublishing. This is not a novel development of the digital age: Numerous renowned authors have distributed their works in this way, some even started their own presses, including Jane Austen, Virginia Woolf, and Derek Walcott (cf. Patterson 2012). While the exact number of self-published books cannot be determined (partly due to the fact that many of them lack an ISBN-number), with the rise of online literary markets, self-publishing has become a trend. 
The great success of self-published books today is confirmed by works such as Still Alice (2007) by Lisa Genova, which, published with iUniverse's print-on-demand service, was translated in over 30 languages and sold over 2.6 million copies, or Ashwin Sanghi's The Rozabal Line (2007), which made Sanghi one of the best-selling English fiction authors in India (cf. Alphonso 2018, n.pag.). Having offered the manuscript to many literary agents and publishers (100 in total), Sanghi self-published and self-marketed his work under the Anglicized anagram Shawn Haigins and the novel immediately became a success. The Immortals of Meluha (2010) by Indian author Amish Tripathi, the first book of The Shiva Trilogy, was also self-published (although with an agent's assistance) before turning into a bestseller, a success matched by the following two parts of the trilogy.

In self- or indie publishing, writers are not only responsible for copy-editing their works but also devise their own marketing and publication strategy by promoting their works on social media, requesting reviews by book bloggers, or submitting their books to literary awards. In turn, they receive the lion's share of sales income. Amazon, for instance, pays royalties of around $70 \%$ of the overall profit of selfpublishing books (compared to $8-10 \%$ standard-royalty paid in the traditional publishing industry), which means that writers can control the pricing of their works and sell their books more cheaply. This might result in smaller sales numbers, but an increase of royalties compared to contracting a book with traditional publishers. However, the fact that the growing trend of self-publishing is greatly afforded by and ultimately contingent on big online retailers - Amazon currently holds a " $42 \%$ share of all adult fiction sales” in self-publishing (cf. Writers' and Artists' Yearbook 2019, n.pag.) - might create new hegemonic force fields, which could potentially curtail the opportunities gained by this novel mode of publishing and distributing Anglophone world literatures.

Nonetheless, independent and self-publishing might be the way forward for Anglophone world literatures in that they not only offer easier access to the global market (see also Vermeulen and Hurkens 2019), but also fairer payments, which would foster diversity within literary culture - a diversity which Philip Pullman and other writers saw dwindling due to writers' exploitation by the big publishing companies. However, self-publishing still has ground to gain in its general esteem. With the more or less open access to the self-publishing market, there is no assessment before books are published. This lack of preselection, often mistaken as quality control, might discourage readers from buying self-published books. Furthermore, the number of newly published indie books is simply overwhelming. As a consequence, readers - often unconsciously - tend to rely on "the traditional publishing market, the reputation of specific publishers, and the forms of commodity production and reward the book market supports, to provide a signal of quality that precedes any literary critical or academic assessment” (Bode 2012, 101).

The digital age, however, also offers new opportunities for this kind of assessment. Online literary magazines, such as Brittle Paper, founded by Nigerian writer 
and scholar Ainehi Edoro, can help build glocal literary markets by publishing fiction, poetry, and essays both from more established and still unknown writers online and by offering critical reviews and assessments of recent works. Brittle Paper is not only committed to "build[ing] a vibrant African literary scene", but also caters its content "for a younger, taste-driven audience" (Brittle Paper, n.pag.), both supporting and marketing African literatures as world literatures. These activities, though often notoriously underfunded, offer alternative modes of assessment, which help counter the dominant role of literary prizes and tend to subvert "the economics of cultural prestige" (English 2005, 4). The latter, however, continues to shape the perception, dissemination, and reception of Anglophone world literatures in the growing attention economy, an economy where value is determined by the (unpaid) attention paid to a specific object (cf. Davenport and Beck 2001) and which also regulates the literary market.

\section{Prestige and Attention Economies in Anglophone Literary Markets}

Besides monitory gain, marketing efforts are increasingly geared towards building authors' reputation as well as towards binding intellectual and cognitive capital. For promoting Anglophone world literatures, literary prizes are indispensable when they are prominent enough to ensure visibility for the award-winning work and its author. To draw the public's attention, the lead-up to the awards, including intense media coverage of the nominees, long- and short-lists, and the publicity gained through award ceremonies, is often governed by an elaborate marketing machine which does not only involve publishers, literary agents, and authors but also journalists, academics, literary critics, and the interested public. The prizes most associated with the aim of promoting Anglophone world literatures are undoubtedly the Booker Prize, described on its webpage as "the leading literary award in the English speaking world" ("About", n.pag.), and the International Booker Prize. Whereas the former is awarded to "the best novel of the year written in English and published in the UK or Ireland" ("The Booker Prize", n.pag.), the latter is bestowed onto a work that has been translated into English and was published in the UK or Ireland.

Though more global, the attention attracted by the International Booker Prize does not come close to the media and marketing hype connected with the Booker whose cultural capital and prestige exceeds its sister-prize by far. Not surprisingly, therefore, the 2019-winner of the Man Booker International, Celestial Bodies (2018) by Omani novelist Jokha Alharthi, though internationally praised, received only a fraction of the attention paid to Booker-prize winners, such as Anna Burns' Milkman (2018), Marlon James' A Brief History of Seven Killings (2015), Aravind Adiga's The White Tiger (2008), or the 2019-award shared by Margaret Atwood's The Testaments 
and Bernardine Evaristo's Girl, Woman, Other (2019). Part of the marketing success of the Booker lies in the elaborate selection process, which moves from a longlist (announced in July) to a shortlist (announced in September) to a gala dinner at Royal Albert Hall (in mid-October) when the winner is announced, closely accompanied by intensive media coverage, which "generates suspense while maximizing commercial appeal” (Huggan 2001, 118). The stickers 'Short-Listed for the Booker Prize' or 'Booker Prize Winner' added to book covers during the selection process and after the announcement of the winner serve as seals of quality, indicating "the particular combination of economic and cultural capital that [...] also generates substantial journalistic capital” (Squires 2016, 75).

Similar to other prizes, including the Nobel Prize which was suspended in 2018 due to allegations of sexual assault and unfair practices, the Booker hovers between idealism and corruption. The several scandals surrounding it, however, have secured the prize's increased public attention. It is one of the curiosities of marketing that critics become the unwilling accomplices of marketers: "there's nothing like a little criticism to fan the marketing flames. [...] Critique, censure, and controversy are the 3Cs of effective marketing communications in our mass-mediated world" (Brown 2005, 59).

The most memorable controversy was sparked by the Booker's roots in colonial exploitation. In his Booker-prize-acceptance speech in 1971, John Berger openly denounced the Booker McConnell company, which founded the prize, as "a colonialist enterprise built on the backs of black plantation workers in Guyana” (English 2005, 203). Consequently, the prize's self-fashioning as a patron of postcolonial literatures has often been regarded as highly problematic, especially as critics repeatedly noted a tendency towards "an Anglocentric discourse of benevolent paternalism" (Huggan 2001, 111). This critique abated with the 'decolonisation' of the Booker in 2014 when the award was broadened to all Anglophone novels published in the UK and Ireland and no longer excluded authors born outside of Britain, the Republic of Ireland, the Commonwealth, Pakistan, and Bangladesh.

Due to its focus on Commonwealth literatures, the Booker was repeatedly associated with promoting 'the postcolonial exotic' (Huggan 2001). Salman Rushdie's Midnight's Children (1981), which won the award in the year of its publication and was deemed the 'best of the Booker' in 2008, was regarded as a key example of "strategically self-conscious exoticism", which was expressed in "a stylishly hybridised literary/cultural text” (Huggan 2001, 116). Rushdie's success and the persistent desire for 'the postcolonial exotic' amongst Anglophone readers sparked new market- and award-driven writing. Both Arundhati Roy's The God of Small Things (1997) and Aravind Adiga's The White Tiger (2008), for instance, seemed to cater to the tastes of Western readers by following the same strategic exoticism that paved the road to success for Rushdie (cf. Huggan 2001). As it is indisputable that commercial considerations also guide authors in their writing, in the Darwinian, neoliberal book market, the fittest are the ones most able to cater to the demands of their target readers while drawing on literary styles that have been favoured by consumers. 
The profound impact of strategic marketing is particularly prominent in recent Southern Asian writing. Ironically, many of these novels reveal an acute awareness of capitalism and neoliberalism that govern the global (book) market (cf. Brouillette $2014,95)$ and addresses the economic forces that also govern the distribution of Anglophone literatures. Adiga's The White Tiger (2008), for instance, depicts the social and economic rise of the entrepreneur Balram from the "India of Darkness" to the "India of Light" (Adiga 2008, 14), which is inspired by the American dream and neoliberal tendencies in India's 'tiger economy', but enabled through ruthless corruption. Balram seems to play the neoliberal capitalist system, but in the end, he becomes part of that very system. The novel, therefore, ultimately works against the wide-spread assumption that Anglophone world literatures might challenge or even subvert the logic of the capitalist world literary market, based on its "immanent resources for resisting capitalist globalization” (Cheah 2016, 11). Instead, Adiga's narrative seems to give a voice to an 'India of Darkness' and ultimately adheres to the unwritten rules of Western capitalist book markets, reinforcing - like Balram - the system that it attempts to destabilize.

As Ana Christina Mendes notes, referring to Adiga's novels, but also to further politically-oriented works, such as Mohsin Hamid's How to Get Filthy Rich in Rising Asia (2013) and Deepti Kapoor's A Bad Character (2014), “[t]hough contemporary South Asian social realist literary works stand as nodes of resistance to the structural inequalities of the capitalist world-system and its enforced translation into other systems in postcolonial contexts, they are usually commercially successful in the West and as such are an integral feature of the expansion of economic neoliberalism" (Mendes 2016, 227). The fact that many of the celebrated South Asian authors were educated in the West and often attended private universities underlines the prevailing dominance of the West in the production of Anglophone world literatures.

Adiga's novel furthermore exposes the increasing significance of consumers' attention in assessing the economic and cultural value of a specific work (cf. Baumbach 2019). While Balram does not succeed in alerting the Chinese Premier to his story (the Premier to whom he addresses his narrative never responds), he fashions himself as a key figure of attention, which secures him prestige and fortune and makes him a key player in the tiger economy of a new, neoliberal India. At the same time, The White Tiger (2008) stresses the need for self-marketing as part of its narrative - a strategy which is critically reflected upon by the use of an unreliable narrator, but which foregrounds the culture of prestige and the attention economy which drive marketing activities connected to Anglophone world literatures.

Literary prizes such as the Booker are not only indicators of public taste and guarantors of successful commercialization. As the list of Booker prize-winning Anglophone writers, including Salman Rushdie (in 1981), J.M. Coetzee (1983/1999), Kazuo Ishiguro (1989), Ben Okri (1991), Michael Ondaatje (1992), and Arundhati Roy (1997), suggests, they also secure canonization (Todd 1996; $>16$ Canons and Canonicity in Anglophone Literature) and therefore long-lasting prestige. Though there is no recipe for the Booker - a point highlighted ironically in St Aubyn's Lost for Words where the 
analogous Elysian Prize is awarded to a cookbook (cf. Baumbach 2018) - writers might tailor their narratives to the expectations of the prize jury. This is confirmed by the dominant topics shared by many shortlisted and winning novels, which tend to focus on aspects of history and identity, individual and cultural memory ( $\nearrow 9$ Anglophone World Literature and Transcultural Memory; cf. Neumann 2019), and narratives of belonging - issues that seem characteristic of Anglophone world literatures.

Some of these aspects are further emphasized once novels are processed by the global marketing machine. As noted by Elizabeth Webby, on entering the Anglophone world literary market, books - or rather their covers - often undergo quite a radical makeover. In its first Australian edition, Peter Carey's award-winning True History of the Kelly Gang (2000), a story about Australian bushranger Ned Kelly, was issued with a plain cream cover and a "light-brown imitation-leather spine", "designed to look like a nineteenth-century book", presenting the novel "as a combination of aesthetic object and historical artefact" (Webby 2016, 67-68) that complies with the narrative. The British publishers Faber and Faber, however, placed a photograph of Ned Kelly on the cover, which encourages a historical reading of the novel as true history in juxtaposition to the narrative. The novel's reduction to a 'true' history propelled by the altered cover further cements the cultural hegemony of the West, which determines which histories are 'true', reliable, and also consumable. What is even more astonishing is Webby's observation that the alteration of novels' covers often signals to an attempt to streamline potentially best-selling fiction by concealing the writers' country of origin. Carey's novel and Tim Winton's Dirt Music (2001), which was shortlisted for the Booker and won the 2002 Miles Franklin Award, the most prestigious literary prize in Australia, provide salient examples. The cover alterations of the novels led Webby to claim that "[i]ndeed, it would seem that publishers have even attempted to conceal the fact that Winton's and Carey's novels are set in Australia, perhaps because quality fiction is not usually associated with Australia in the way that crocodiles and the outback are" $(2016,64)$.

Entering the global market comes at a cost in that it might alienate and distract narratives from their local contexts rather than fostering a 'glocal' marketing and reading culture, which acknowledges the origins of these novels while supporting their travelling across the Anglophone world (cf. Apter 2013).

\section{Conclusion: How to Market Anglophone World Literatures}

While Sarah Brouillette claimed that "participation in the literary economy is a mark of privilege" $(2015,98)$, in a world increasingly pressured to engage in global capitalist economies, it is a mark of privilege to return to, recognize, and promote local literary markets. As suggested in Coetzee's Elizabeth Costello, it is in these markets 
that 'authentic' novels arise, which might eventually be recognized as Anglophone world literatures, but essentially resist the external economic pressures and "regime of enforced mobility" (Mufti 2016, 9), prompted by the Western market. Paradoxically, some world-leading online retailers only use the rubric world literature as an umbrella term. On Amazon, for instance, no literary works are listed under this rubric. Instead, it embraces all national literatures and thus implicitly acknowledges the glocality of Anglophone world literatures, which might be marketed globally but are rooted in specific local, regional, and national cultures.

Even though the Anglophone literary market is heavily regulated by large publishing houses, (online) retailers, literary agents, and prize cultures, which - sometimes in competition, sometimes (when it comes to promoting prize-winning novels) in collaboration - develop marketing strategies to draw readers' attention to their products, writers, and winners respectively, the book market is unpredictable. It is impossible to determine which book will grow into a bestseller. As suggested by John Thompson, "much about this dynamic [...] could be regarded as illogical, irrational and inefficient, not to mention wasteful" (2010, 294). This is confirmed by the fact that even writers who expressed a profound distaste for marketing, such as Chilean novelist Roberto Bolaño, are caught up, often posthumously, in the Anglophone world literature marketing machine (cf. Zavala 2017, 79).

The most unpredictable factor in marketing, however, are readers. Especially in the digital era, profit- and prestige-driven marketing processes are often overruled by “real readers' books” (Wagner 2017, 105): “[t]he books in England that have become huge, from Sebastian Faulks' Birdsong, to Harry Potter, to David Nicholls' One Day (2009) - none of those are books that have had marketing campaigns behind them" (Wagner 2017, 105), at least not at the outset of their success stories when sales were driven solely by readers' demand. J.K. Rowling's Harry Potter novels (1997-2007), for instance, stormed the bestseller lists across several countries in a considerably short period. Whether these works will stand the test of time remains to be seen, but the hype surrounding them was, at least to begin with, not tied to specific marketing strategies. The media marketing machine, which included the film industry that turned the books into popular movies, as well as the memorabilia that further boosted sales of the Harry Potter brand, began to operate only after Rowling's novels had already reached a broad readership. Furthermore, it is largely governed by Rowling herself, which again highlights the importance of self-marketing activities. In addition to self-promotion on social media, “the Rowling machine” (Jordison 2011, n.pag.) launched Pottermore.com, which turns fans into "devotee[s]" (Jordison 2011, n.pag.), eager to sponge up any snippets from the wizarding world provided on the website.

Anglophone world literature is not a brand. At least not yet. It could develop into one, but only if it affirms that it is not customer-led. As Stephen Brown, who has investigated the enormous success of the Harry Potter brand, has suggested, "great brands [...] appear when it suits them. [...] They invite us to participate, partake, experience, enjoy. But they won't do as they're told. [...] [T]hey aren't customer-centric 
[but] concept-centric” (2005, 74). Furthermore, brands have to retain something unfathomable: "great brands are a puzzle. They are inexplicable, enigmatic, mysterious. They reveal their secrets slowly" $(2005,74)$. And finally, "great brands are storied. They attract tales and taletellers" $(2005,75)$. Branding Anglophone world literatures, therefore, can only happen from within - through 'the sea of stories' (Rushdie 1990) told on a regional, national, and essentially glocal level at which they should be matched with marketing activities which acknowledge the diversity and glocality of Anglophone world literatures while enabling their travelling without covering up their origin. The challenge will be to support the mondialisation of Anglophone literatures by novel marketing strategies that aim "to take in the whole world" (Twain 1996 [1873], v) while preserving a sense of the untranslatable.

\section{Bibliography}

\subsection{Works Cited}

"About." The Booker Prizes (n.d.). https://thebookerprizes.com/fiction/about (20 Jan. 2020). African Books Collective (n.d.). www.africanbookscollective.com (20 Jan. 2020).

Alfredsson, Henrik. "Her Mission: to Bring African Books to a Global Audience." The Nordic Africa Institute (07 June 2017). https://nai.uu.se/news/articles/2017/06/07/144445/index.xml (05 Oct. 2019).

Alphonso, Brianne. "11 Books that Prove there's Nothing Wrong with Self-Publishing." Electric Literature (3 Aug. 2018). https://electricliterature.com/11-books-that-prove-theres-nothingwrong-with-self-publishing/ (12 Dec. 2019).

Applbaum, Kalman. The Marketing Era: From Professional Practice to Global Provisioning. New York and London: Routledge, 2004.

Apter, Emily. Against World Literature: On the Politics of Untranslatability. London: Verso, 2013.

Arts Council England. Literature in the 21st Century: Understanding Models of Support for Literary Fiction. London: Canelo, 2017.

Baumbach, Sibylle. "The Economy of Attention and the Novel." New Approaches to the 21st-Century Anglophone Novel. Ed. Sibylle Baumbach and Birgit Neumann. Basingstoke: Palgrave Macmillan, 2019. 39-58.

Baumbach, Sibylle. "The Booker Prize as a Harbinger of Literary Trends and an Object of Satire: Debates about Literary Prizes in Journalism and Edward St Aubyn's Lost for Words." The British Novel in the Twenty-First Century: Cultural Concepts - Literary Developments - Model Interpretations. Ed. Vera Nünning and Ansgar Nünning. Trier: WVT, 2018. 53-70.

Baverstock, Alison. How to Market Books. Abingdon and New York: Routledge, 2015.

Bode, Katherine. Reading by Numbers: Recalibrating the Literary Field. London: Anthem Press, 2012. Brittle Paper. https://brittlepaper.com/about/ (08 Dec. 2019).

Brouillette, Sarah. Literature and the Creative Economy. Stanford: Stanford University Press, 2014. Brouillette, Sarah. "World Literature and Market Dynamics." Institutions of World Literature: Writing, Translation, Markets. Ed. Stefan Helgesson and Pieter Vermeulen. New York: Routledge, 2015. 93-108. 
Brown, Stephen. Wizard! Harry Potter's Brand Magic. London: Cyan, 2005.

Casanova, Pascale. The World Republic of Letters. Trans. Malcolm B. DeBevoise. Cambridge, MA and London: Harvard University Press, 2004 [1999].

Cheah, Pheng. What is a World? On Postcolonial Literature as World Literature. Durham: Duke University Press, 2016.

Coetzee, J.M. Elizabeth Costello. Eight Lessons. London: Secker \& Warburg, 2003.

Davenport, Thomas, and John Beck. The Attention Economy: Understanding the New Currency of Business. Brighton, MA: Harvard Business School Press, 2001.

English, James F. The Economy of Prestige: Prizes, Awards, and the Circulation of Cultural Value. Cambridge, MA: Harvard University Press, 2005.

Huggan, Graham. The Postcolonial Exotic: Marketing the Margins. London: Routledge, 2001.

Jordison, Sam. “Pottermore gives away JK Rowling’s Marketing Genius.” The Guardian (23 June 2011). https://www.theguardian.com/books/booksblog/2011/jun/23/pottermore-jk-rowlingmarketing-genius-harry-potter (12 Dec. 2019).

Kean, Danuta. "Publishers are Paying Writers a Pittance, Say Bestselling Authors." The Guardian (27 June 2018). https://www.theguardian.com/books/2018/jun/27/publishers-pay-writerspittance-philip-pullman-antony-beevor-sally-gardner (20 Jan. 2019).

Mani, B. Venkat. "Bibliomigrancy: Book Series and the Making of World Literature." The Routledge Companion to World Literature. Ed. Theo D'haen, David Damrosch, and Djelal Kadir. London and New York: Routledge, 2012. 283-296.

Mani, B. Venkat. Recoding World Literature: Libraries, Print Culture, and Germany's Pact with Books. New York: Fordham University Press, 2017.

Mendes, Ana C. “The Marketing of Postcolonial Literature.” Postcolonial Studies Meets Media Studies: A Critical Encounter. Ed. Kai Merten and Lucia Krämer. Bielefeld: transcript, 2016. 215-231.

Morris, Christopher D. "Hermeneutic Delusion in Mark Twain and Charles Dudley Warner's The Gilded Age.” Nineteenth-Century Literature 66.2 (2011): 219-243.

Mufti, Aamir R. Forget English! Orientalisms and World Literatures. Cambridge, MA: Harvard University Press, 2016.

Nancy, Jean-Luc. The Creation of the World or Globalization. Trans. Francois Raffoul and David Pettigrew. New York: State University of New York Press, 2004.

Neumann, Birgit. "Anglophone World Literature and Glocal Memories: Chimamanda Ngozi Adichie’s Half of a Yellow Sun and Kiran Desai's The Inheritance of Loss." New Approaches to the 21st-Century Anglophone Novel. Ed. Sibylle Baumbach and Birgit Neumann. Basingstoke: Palgrave Macmillan, 2019. 217-236.

Neumann, Birgit, and Gabriele Rippl. “Anglophone World Literatures: Introduction.” Special issue Anglophone World Literatures. Anglia 135.1 (2017): 1-20.

Patterson, Christina. "How the Great Authors Published Themselves." The Independent (18 Aug. 2012). https://www.independent.co.uk/arts-entertainment/books/features /how-the-great-writers-published-themselves-8053570.html (20 Jan. 2020).

Pizer, John. "Johann Wolfgang von Goethe: Origins and Relevance of Weltliteratur." The Routledge Companion to World Literature. Ed. Theo D'haen, David Damrosch, and Djelal Kadir. London and New York: Routledge, 2012. 3-11.

Prado, Ignacio M. Sanchez. Strategic Occidentalism: On Mexican Fiction, the Neoliberal Book Market, and the Question of World Literature. Evanston: Northwestern University Press, 2018.

Puchner, Martin. “Readers of the World Unite.” Aeon (20 Sept. 2017). https://aeon.co/essays/ world-literature-is-both-a-market-reality-and-a-global-ideal (12 Dec. 2019).

Rushdie, Salman. Haroun and the Sea of Stories. London: Granta, 1990. 
Squires, Claire. Marketing Literature: The Making of Contemporary Writing in Britain. Basingstoke: Palgrave Macmillan, 2007.

Squires, Claire. "Book Marketing and the Booker Price." Judging a Book by Its Cover: Fans, Publishers, Designers, and the Marketing of Fiction. Ed. Nicole Matthews and Nickianne Moody. Abingdon and New York: Routledge, 2016. 71-82.

Steiner, Ann. "The Global Book: Micropublishing, Conglomerate Production, and Digital Market Structures." Publishing Research Quarterly 34 (2018): 118-132.

Steiner, Ann. "World Literature and the Book Market." The Routledge Companion to World Literature. Ed. Theo D'haen, David Damrosch, and Djelal Kadir. London and New York: Routledge, 2012. 316-324.

"The Agent: How to Pitch Your Book." Penguin (n.d.). https://www.penguin.co.uk/articles/company/ blogs/the-agent-how-to-pitch-your-book-/ (14 May 2020).

“The Booker Prize.” The Booker Prizes (n.d.). https://thebookerprizes.com/ (20 Jan. 2020).

Thompson, John B. Merchants of Culture: The Publishing Business in the Twenty-First Century. Cambridge: Polity, 2010.

Todd, Richard. Consuming Fictions: The Booker Prize and Fiction in Britain Today. London: Bloomsbury, 1996.

Twain, Mark, and Charles Dudley Warner. The Gilded Age: A Tale of Today. Ed. Shelley Fisher Fishkin. Oxford and New York: Oxford University Press, 1996 [1873].

Vermeulen, Pieter, and Amélie Hurkens. "The Americanization of World Literature? American Independent Publishing and World Literary Vernacular." Interventions 22.3 (2019): 1-18.

Wagner, Erica. "Literary Reviews: Past, Present, Future." The Literary Market in the UK. Ed. Amrei K. Nensel and Christoph Reinfandt. Tübingen: Eberhard Karls University, 2017. 101-108.

Webby, Elizabeth. "Literary Prizes, Production Values and Cover Images." Judging a Book by Its Cover: Fans, Publishers, Designers, and the Marketing of Fiction. Ed. Nicole Matthews and Nickianne Moody. Abingdon and New York: Routledge, 2016. 63-70.

Writers' and Artists' Yearbook 2019. London: Bloomsbury, 2018.

Xavier, Subha. The Migrant Text: Making and Marketing a Global French Literature. Montreal: McGill-Queen's University Press, 2016.

Zavala, Oswaldo. "The Repolitization of the Latin American Shore: Roberto Bolaño and the Dispersion of 'World Literature." Roberto Bolaño as World Literature. Ed. Nicholas Birns and Juan E. De Castro. New York: Bloomsbury, 2017. 79-101.

\subsection{Further Reading}

Davis, Caroline. Creating Postcolonial Literature: African Writers and British Publishers. London: Palgrave Macmillan, 2013.

Delany, Paul. Literature, Money and the Market: From Trollope to Amis. Basingstoke: Palgrave Macmillan, 2002.

Erickson, Lee. The Economy of Literary Form: English Literature and the Industrialization of Publishing, 1800-1850. Baltimore: The John Hopkins University Press, 1996.

Helgason, Jon, Sara Kärrholm, and Ann Steiner, eds. Hype: Bestsellers and Literary Culture. Lund: Nordic Academic Press, 2014.

Koegler, Caroline. Critical Branding: Postcolonial Studies and the Market. New York: Routledge, 2018.

Walkowitz, Rebecca. Born Translated. The Contemporary Novel in an Age of World Literature. New York: Columbia University Press, 2015. 
Young, Robert J.C. "World Literature and Postcolonialism.” The Routledge Companion to World Literature. Ed. Theo D’haen, David Damrosch, and Djelal Kadir. London and New York: Routledge, 2012. 213-222.

Zell, Hans. M. “Publishing in Africa: The Crisis and the Challenge.” A History of Twentieth-Century African Literatures. Ed. Oyekan Owomoyela. Lincoln and London: University of Nebraska Press, 1993. 369-388. 
